\title{
Photocatalytic Removal of Malachite Green and Brilliant Blue Dyes from its Aqueous Solution: A Case Study of Factorial Experimental Design
}

\author{
Zainab Haider Mussa ${ }^{1,2}$, Fouad Fadhil Al-Qaim ${ }^{1,3 *}$, Ali Yuzir ${ }^{1}$, Kamyar Shameli $^{1}$ \\ ${ }^{1}$ Malaysia-Japan International Institute of Technology (MJIIT), Universiti Teknologi Malaysia, Jalan Sultan \\ Yahya Petra,54100 Kuala Lumpur. \\ ${ }^{2}$ College of Pharmacy, University of Al-Ameed, Karbala PO Box 198, Iraq. \\ ${ }^{3}$ Department of Chemistry, Faculty of Science for Women, University of Babylon, PO Box 4, Hilla, Iraq.
}

*Corresponding author: Fouad Fadhil Al-Qaim, email: fouadalkaim@yahoo.com, tel: +60173394821.

Received April 3 ${ }^{\text {rd }}$, 2020; Accepted January 23 ${ }^{\text {rd }}, 2021$.

DOI: http://dx.doi.org/10.29356/jmcs.v65i2.1356

\begin{abstract}
In this present study, the investigation of the photocatalytic removal of malachite green and brilliant blue dyes from their aqueous solution using photocatalytic oxidation process was provided. The application of factorial experimental design for the analysis the results was the main objective in the present study. The photocatalytic removal of Malachite Green (MG) and Brilliant Blue (BB) dyes was carried out in aqueous solutions containing the dye and suspended of $\mathrm{ZnO}$ upon UV irradiation (high pressure mercury lamp Radium $125 \mathrm{~W}$ ). The effect of different factors such as initial dye concentration, sample volume and treatment time was taken in account. All samples of MG and BB have been analysed at 617 and $620 \mathrm{~nm}$, respectively. The linearity ranged between 5 and $50 \mathrm{mg} / \mathrm{L}$ for MG dye while it was ranged between 20 and $200 \mathrm{mg} / \mathrm{L}$ for BB dye. The linear regression, $\mathrm{R} 2$, was more than 0.995 for both dyes. The results revealed that factorial experimental design analysis has given a better indication to investigate the effects of factors. It was observed that the most of factors are significant for both dyes. Initial concentration and treatment time factors were the most significant factors for MG and BB dyes, respectively according to pareto chart.

Keywords: Malachite green dye; brilliant blue dye; factorial experimental design; photocatalytic process.

Resumen. En este estudio se presenta una investigación sobre la remoción fotocatalítica de colorantes de verde de malaquita y azul brillante de soluciones acuosas mediante procesos de oxidación fotocatalítica. El objetivo principal de este trabajo fue la aplicación de un diseño experimental factorial para el análisis de los resultados. La remoción del verde de malaquita (MG) y azul brillante (BB) de soluciones acuosas se llevó a cabo mediante irradiación de luz UV en presencia de partículas de $\mathrm{ZnO}$ en suspensión. Para los experimentos, se usó una lámpara de mercurio a alta presión (Radium $125 \mathrm{~W}$ ). Se consideraron los efectos de distintas variables, como la concentración inicial de cada colorante, el volumen de la muestra y el tiempo de tratamiento. Todas las muestras de MG y BB se analizaron a 617 y $620 \mathrm{~nm}$, respectivamente. Se observó linealidad en los resultados en el intervalo de concentraciones entre 5 y $50 \mathrm{mg} / \mathrm{L}$ para el caso de $\mathrm{MG}$, mientras que para el BB la linealidad se observó en el intervalo de concentraciones entre 20 y $200 \mathrm{mg} / \mathrm{L}$. En ambos casos, los datos se ajustaron a modelos lineales con valores de $\mathrm{R}^{2}$ mayores a 0.995 . Los resultados revelaron que el diseño experimental factorial permite investigar de mejor manera los efectos de diversos factores, encontrándose que la concentración inicial y el tiempo de tratamiento son los factores más importantes para la remoción de MG y $\mathrm{BB}$, respectivamente, según se muestra en los gráficos de Pareto.
\end{abstract}

Palabras clave: Verde de malaquita, azul brillante, diseño experimental factorial, procesos fotocatalíticos. 


\section{Introduction}

Dyes are toxic pollutants, which are used for dyeing textiles, paper industries, antibacterial agent, food staff and carpet manufacturing [1]. Malachite green (MG) dye is a water-soluble dye has been used as an antibacterial and antifungal agent, as a dye for cloth and leather, and as a wound disinfectant [2].

Brilliant Blue (BB) dye is a synthetic food colorant which is used in colouring of beverages, papers and so many other things [3].Non-destructive treatment of dyes may make it stable and present in water then it can affect photosynthetic activity due to reduced light penetration and may also be a source of toxicity for aquatic life $[4,5]$. The traditional methods for the treatment of dye effluent are inadequate because dyes are resistant due to their complex aromatic molecular structures [6-10]. The addition of chlorine and ozone to the water sample is considered successful chemical treatment but they are costy due to its high dosages need. However, looking for alternative degradation process such as photocatalytic process is necessary to ensure that dyes could be eliminated in water samples.

The principle of this method is the generation of very reactive agents, hydroxyl radicals $\left(\mathrm{OH}^{\wedge} \mathbf{m}\right)$, that are extremely reactive and strong oxidizing agent $\left(\mathrm{E}_{\mathrm{o}}=2.8 \mathrm{~V}\right)$ [11].The following equations (1-3) are the main route for the mechanism of photooxidation process as reported by [12].

$$
\begin{aligned}
& \mathrm{ZnO}+\mathrm{hv} \rightarrow \mathrm{e}^{\wedge}-\mathrm{CB}+\mathrm{h}^{\wedge}+\mathrm{VB} \\
& \mathrm{O} \_2+\mathrm{e}^{\wedge}-\mathrm{CB} \rightarrow \mathrm{O}_{-} 2^{\wedge}(\mathbf{\square}-) \\
& \mathrm{H} \_2 \mathrm{O}+\mathrm{h}^{\wedge}+\mathrm{VB} \rightarrow \mathrm{OH}^{\wedge} \mathbf{\square}+\mathrm{H}^{\wedge}+
\end{aligned}
$$

It has been suggested that the hydroxyl radicals $\left(\mathrm{OH}^{\wedge} \mathbf{\square}\right)$ and superoxide radical anions $\left(\mathrm{O}_{-} 2^{\wedge}(\mathbf{\square}-)\right)$ are the primary oxidizing species in the photocatalytic oxidation processes. Visible light has been applied for degradation of different dyes and pharmaceuticals using $\mathrm{ZnO}$ composite. It exhibited very high potential for environmental remediation [13,14]. Factorial experimental design is one of the powerful program software which is used for finding a set of process factors. In this study, factorial experimental design is required to determine the levels that all factors must be kept to optimize the process performance. The aim of this study is to investigate the colorremoval of $\mathrm{MG}$ and $\mathrm{BB}$ dye in water samples in the presence of $\mathrm{ZnO}$.

Furthermore, it aims to optimize different factors such as initial dye concentration, sample volume and treatment time for the removal of MG and BB dyes using full factorial experimental design to give more investigations about the removal of these dyes under different conditions.

\section{Experimental}

\section{Reagents}

Zinc Oxide, ZnO, was obtained from Merck (Germany). The used Malachite green (CAS no. 569-642) and Brilliant blue (CAS no. 3844-45-9) dyes were obtained from Sigma- Aldrich (Germany) and they used without any further purification. The molecular structures of both dyes were shown in Fig. 1(a), (b). The maximum wavelengths of malachite green and brilliant blue dyes were 617 and $620 \mathrm{~nm}$, respectively. 


\section{Preparation of solutions}

Stock solutions of dyes were prepared by dissolving $0.01 \mathrm{~g}$ in $10 \mathrm{~mL}$ of double distilled water DDW and stored at $4^{\circ} \mathrm{C}$ for further preparation. Further solutions were prepared by diluting the stock solution in DDW.

All solutions were analysed in triplicate using UV-visible spectrophotometry. Calibration curves were built by plotting absorbance against concentration. The linearity ranged between 5 and $50 \mathrm{mg} / \mathrm{L}$ for MG and for $\mathrm{BB}$, it was ranged between 20 and $200 \mathrm{mg} / \mathrm{L}$.

The linear regression model, $\mathrm{R}^{2}$, was $\geq 0.995$ for both dyes.

\section{Septup the photocatalytic cell}

The reaction mixture was carried out using $250 \mathrm{~mL}$ pyrex glass reservoir placed in the laboratory. Pyrex glass beaker was surrounded by cellophane cover to keep light inside vessel and this cover is provided with hole to pass air. Pyrex glass beaker containing dye sample $(100,200 \mathrm{~mL})$ and $\mathrm{ZnO}$ as photo-catalyst was placed in the reaction vessel.

The concentrations of malachite green and brilliant blue dyes were $(10$ and $40 \mathrm{mg} / \mathrm{L})$ and $(50$ and 100 $\mathrm{mg} / \mathrm{L})$, respectively. Light source was focused directly on the solution as shown in Fig. 1(c). Colour removal of dyes was assessed by Uv-Visible Spectrophotometer by fixing the maximum wavelength $\lambda_{\max }$ for each dye. After that, absorbance was converted to concentration by applying the calibration curve model. Initial concentration of dye $(\mathrm{mg} / \mathrm{L})$, volume sample $(\mathrm{mL})$ and treatment time $(\mathrm{min})$ factors were tested at once using full factorial experimental design.

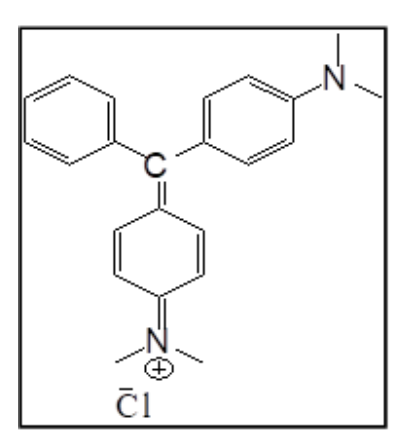

(a)

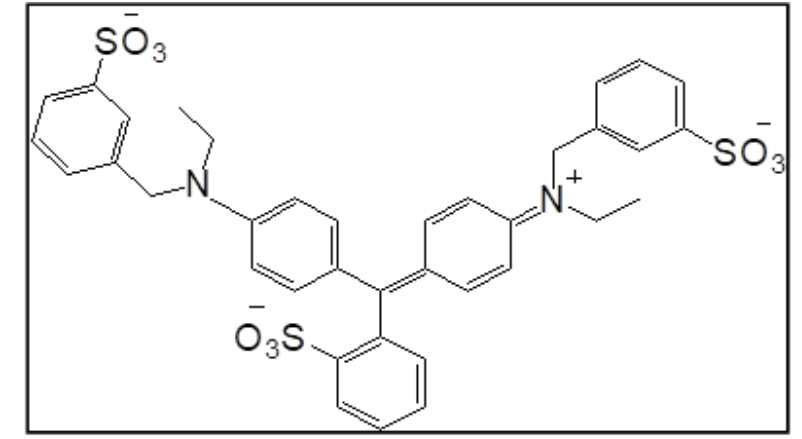

(b)

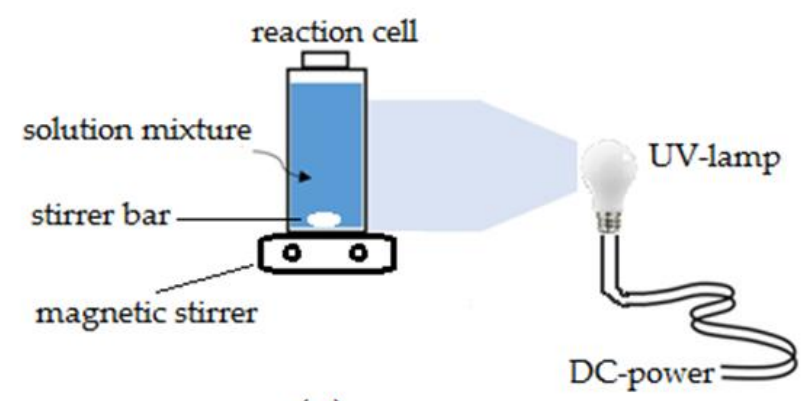

(c)

Fig. 1. The molecular structure of (a) Malachite Green, (b) Brilliant Blue and (c) Set up of photocatalytic cell. 


\section{Statistical analysis}

The more impact factor could be observed using factorial design stating that which factor influences the variation of one factor on the other factors. The three factors were varied at two levels $(+1,-1)$, as shown in Table 1. Each assay was repeated at least three times. Means were analysed statistically by analysis of variance (ANOVA) followed by Duncan's test, using MINITAP software, Version 17. The results were considered significantly different at $p<0.05$.

Table 1. High and low levels for all three parameters.

\begin{tabular}{|c|c|c|c|c|c|c|}
\hline \multirow[t]{4}{*}{ (2) } & \multicolumn{6}{|c|}{ Factors } \\
\hline & \multicolumn{2}{|c|}{$\begin{array}{l}\text { Treatment time } \\
\quad(\text { min) }(A)\end{array}$} & \multicolumn{2}{|c|}{$\begin{array}{c}\text { Initial } \\
\text { concentration(mg/L) } \\
(B)\end{array}$} & \multicolumn{2}{|c|}{$\begin{array}{l}\text { Sample volume }(\mathbf{m L}) \\
\text { (C) }\end{array}$} \\
\hline & $\begin{array}{l}\text { Low } \\
\text { level }\end{array}$ & $\begin{array}{l}\text { High } \\
\text { level }\end{array}$ & $\begin{array}{l}\text { Low } \\
\text { level }\end{array}$ & High level & $\begin{array}{l}\text { Low } \\
\text { level }\end{array}$ & High level \\
\hline & -1 & +1 & -1 & +1 & -1 & +1 \\
\hline $\begin{array}{l}\text { Malachite } \\
\text { Green }\end{array}$ & 15 & 30 & 10 & 40 & 100 & 200 \\
\hline Brilliant Blue & 10 & 30 & 50 & 100 & 100 & 200 \\
\hline
\end{tabular}

\section{Results and discussion}

\section{Photocatalytic performance process}

It was observed that, photocatalytic removal of dye depends on initial concentration of dye, sample volume and treatment time. In the routine experiments work, only one factor is varied by time and the others are fixed during the optimization process. Subsequently, the best value obtained by this procedure is fixed and other factors will be changed; thus, this univariate procedure is time consuming to optimize all variables. The interactions among all the factors are neglected in this procedure, so the best condition could not be achieved as reported in previous studies [15-17].

In order to solve this, full factorial experimental design of experiments was performed by practicing with different levels of factors as reported previously [18]. The results of the experimental design in terms of the evaluation effects were analysed using MINITAB 17 statistical software.

Twenty-four experiments were tested, ( 8 experiments $\times 3$ replications), for each dye using $2^{3}$ full factorial design. The matrix was constructed based on the high and low value levels, represented by +1 and -1 , respectively. Four standard plots are discussed, main effects, normal probability of the standardized effects, pareto chart effects and interaction plots. Initial dye concentration, sample volume and treatment time were significant at a $5 \%$ of probability level $(P<0.05)$. Equations 4 and 5 refer to $2^{3}$ factorial experimental design for removal of $\mathrm{MG}$ and $\mathrm{BB}$, respectively.

$$
\begin{aligned}
& R \%(M G)=138.87-2.057 A-3.032 B-0.3001 C+0.1797 A B+ \\
& 0.01845 A C+0.00584 B C-0.001082 A B C
\end{aligned}
$$

$$
\begin{aligned}
& R \%(B B)=135.8-1.700 A-0.813 B-0.3855 C+0.03307 A B+ \\
& 0.01528 A C+0.003523 B C-0.000177 A B C
\end{aligned}
$$


where, $R \%$ is the removal\% of dye, $A$ is the treatment time ( $\mathrm{min}), B$ is the initial concentration of dye $(\mathrm{mg} / \mathrm{L})$, and $C$ is the sample volume $(\mathrm{mL})$.

\section{Main effect plot}

The main effects plot showed that primary factor of interest in the experiment $(A, B$ and $C)$ on removal $\%$ for Malachite green and Brilliant blue dyes. The effect of a factor means the change in removal percentages produced due to the change in level of factor. It was concluded that the larger the vertical line is, the larger the change in removal $\%$ when it is changing from low level -1 to high level +1 .

From Fig. 2(a),(b) it was observed that the removal of MG and BB dyes under effect of initial dye concentration and sample volume was decreased from high to low value while the removal of both dyes under effect of treatment time was increased. The reason may be attributed to the factor effect which is negative trend, i.e. changed from low to high levels or positive effect which mean changed from high to low levels.

However, the removal of MG and BB dyes was decreased from 92 to $39 \%$ and from 82 to $74 \%$ when the concentration increased from 10 to $40 \mathrm{mg} / \mathrm{L}$ and from 50 to $100 \mathrm{mg} / \mathrm{L}$, respectively. In the case of sample volume, the removal was also decreased from 83 to $48 \%$ and from 81 to $74 \%$, respectively when the sample increased from 100 to $200 \mathrm{~mL}$.

In contract, the removal of MG and BB dyes was decreased from 74 to $57 \%$ and 88 to $71 \%$, respectively when the treatment time increased from 15 to $30 \mathrm{~min}$ and from 10 to $30 \mathrm{~min}$, respectively.

\section{Normal probability plot effect}

The normal probability plot of the standardised effects with $\mathrm{P}=0.05$ was considered to evaluate the significance of all factors and their interactions on the removal\%.

Normal probability plot could be separated into two regions; right and left. The right region includes positive coefficients while the left includes negative coefficients.

However, initial concentration has a very big effect on the removal treatment for Malachite green in which the factor $\mathrm{A}$ is the closest to the centre. On the contrary, treatment time has an observed effect on the removal of Brilliant blue dye as shown that the factor B is the closest to the line. The significance of initial concentration, sample volume and treatment time on removal was evaluated by normal probability plot as shown in Fig. 2(c), (d).

Normal probability plot could be separated into two regions, the region with percent $67 \%$ where the factors were indicated negative coefficients $(B, C, B C, A B C$ and $A C)$ and the region with percent $33 \%$ where the factors were indicated positive coefficients $(A B$ and $A)$. All these factors and interactions denoted as a square were significant as shown in Fig. 2(c) which refers to Malachite green dye removal. However, the determination of significance and insignificance factor of each effect are depending accurately on the normal probability plot.

From Fig. 2(d), the non-significant factors fall along a straight line, and tend to be centered near zero. Two interactions effects are non-significant $(A C$ and $B C)$ as described in Fig. 2(d) for BB dye. In case of MG dye, all factors are significant, but the most significant factor is the initial concentration $(B)$, sample volume $(C)$ and the interaction factor between initial concentration and sample volume $(B C)$. 


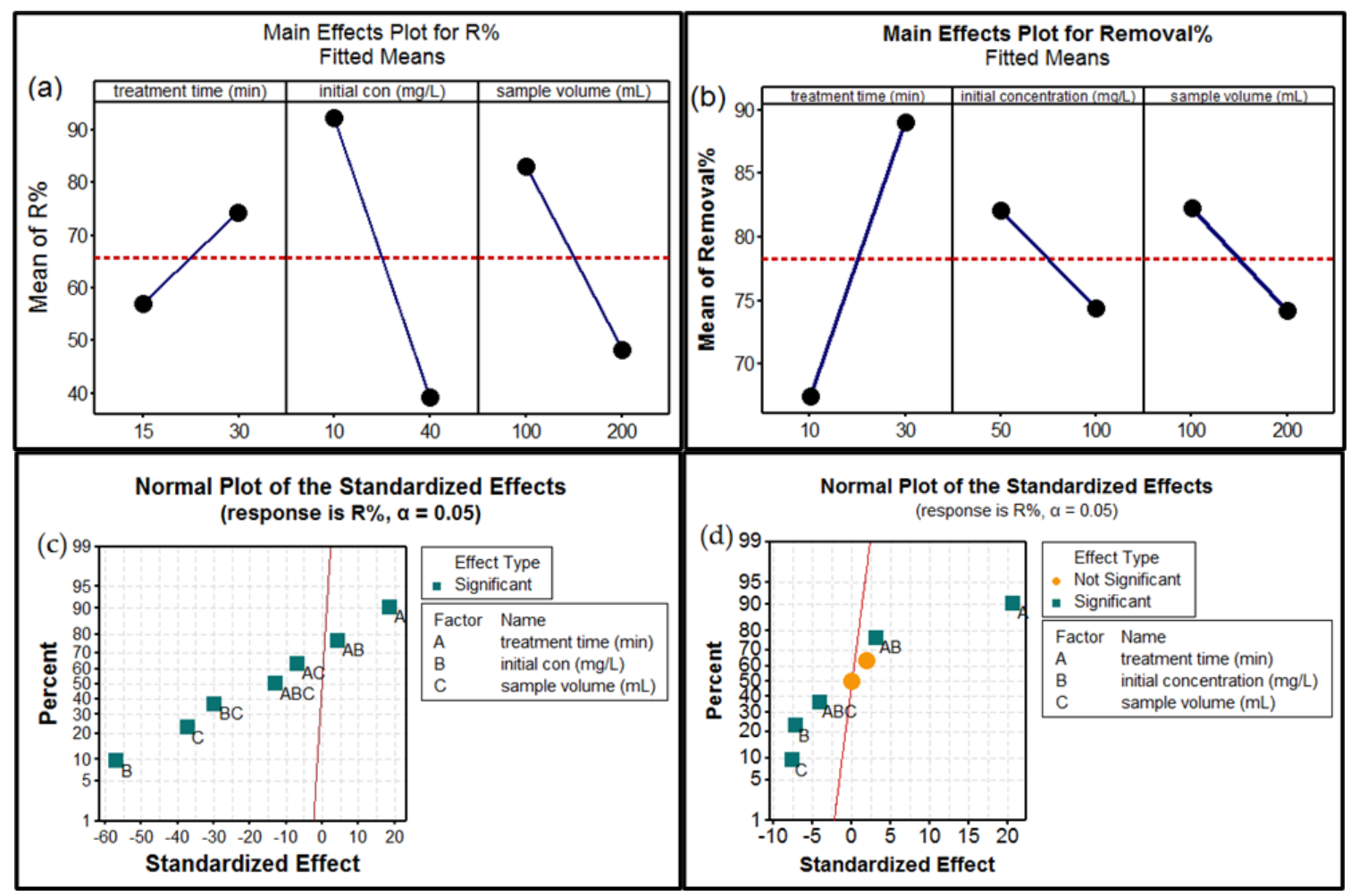

Fig.2. (a) Main effect plot for the removal efficiency (\%) of Malachite Green dye; (b) Main effect plot for the removal efficiency (\%) of Brilliant blue dye; (c) Normal probability plot of the standardized effects at $\mathrm{P}=0.05$ of Malachite Green dye; (d) Normal probability plot of the standardized effects at $\mathrm{P}=0.05$ of Brilliant Blue dye.

\section{Pareto chart effect}

The combination of individual and interaction effect was presented in Fig. 3(a), (b) pareto chart. In order to identify whether the factors were significant or non-significant, student's $t$ test value for each effect factor was performed at $95 \%$ confidence level. The horizontal column in pareto chart showed the value for each factor. The minimum statistically significant effect magnitude for $95 \%$ confidence level is represented by the vertical line in the chart (2.12).

For MG dye, it was observed that all factors and their interactions are significant because they present an absolute value higher than 2.12 as located right of the dashed line. The Pareto chart also emphasizes the strong influence of initial concentration of MG dye and sample volume on the color removal of MG dye as they are the farthest to the right. This is due to the fact that photo-removal process response is inversely dependent on number of dye molecules in solution. For BB dye removal, all factors are significant except two interaction factors (AC and BC). However, the effect of treatment time (factor A) is the strongest compared to initial concentration and sample volume as shown in pareto chart (Fig. 3(b)) because it is the farthest to the right. In terms of photochemical reaction, the reason may relate to the direct relation between the time of treatment and the color removal of BB dye. 

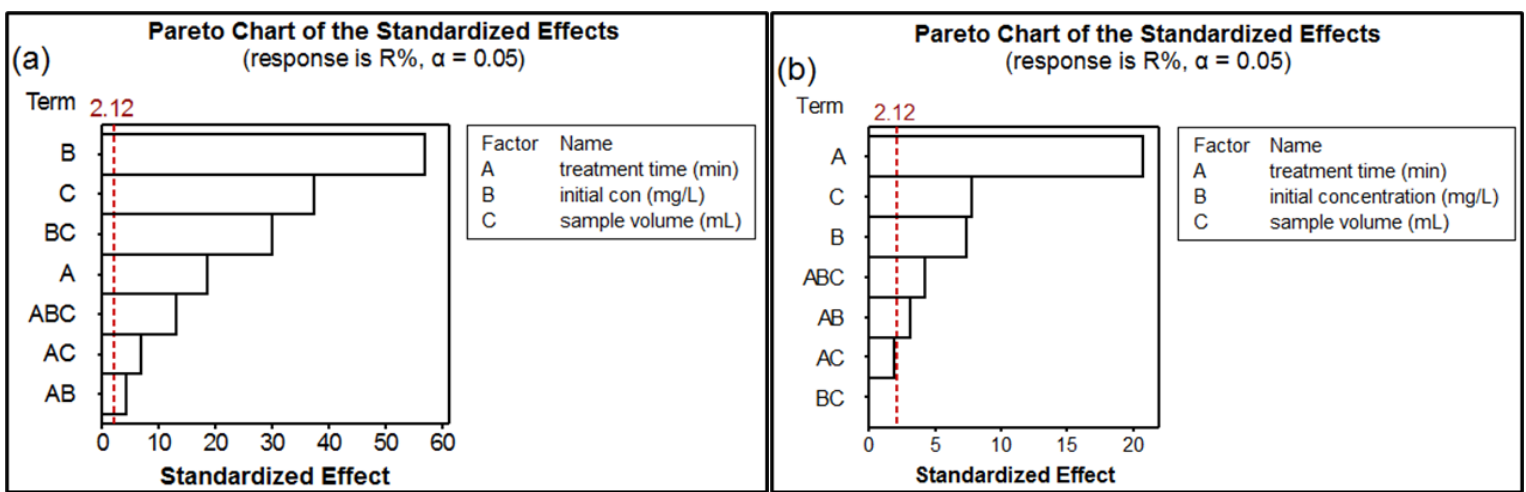

Fig.3. Pareto chart of standardized effects on the removal efficiency (\%) for (a) Malachite green dye and (b) Brilliant blue dye.

\section{Interaction plot effect}

In case of MG dye, the effect of sample volume is very noticeable when the initial concentration is high $(40 \mathrm{mg} / \mathrm{L})$ as shown in Fig. 4(a). In contrary, there is no any effect for sample volume at low initial concentration $(10 \mathrm{mg} / \mathrm{L})$.

The reason is related to the number of dye molecules in solution. It is well known that high concentration in large volume means high number of molecules is present. In the case of low concentration, 10 $\mathrm{mg} / \mathrm{L}$, the number of molecules will not be much different either in small or large volume so that is why no any effect of sample volume at low concentration.

Furthermore, the effect of initial concentration is also significant against treatment time, which means at two values of treatment time, the removal of MG was observed strongly, the gap between two parallel lines are big. This is related to the fact that the removal of MG is much impacted by the concentration level. High concentration solution reduces the intensity of light that pass to the solution resulting low removal\% compared to the low concentration solution. However, there is no any significant effect at $10 \mathrm{mg} / \mathrm{L}$ when the sample volume increased from 100 to $200 \mathrm{~mL}$.

In case of BB dye, Fig. 4(b) shows that the effect of initial concentration and sample volume is significant compare to initial concentration and treatment time. From this chart, better color removal of Brilliant Blue dye when the initial concentration and sample volume are low, $50 \mathrm{mg} / \mathrm{L}$ and $100 \mathrm{~mL}$, respectively.
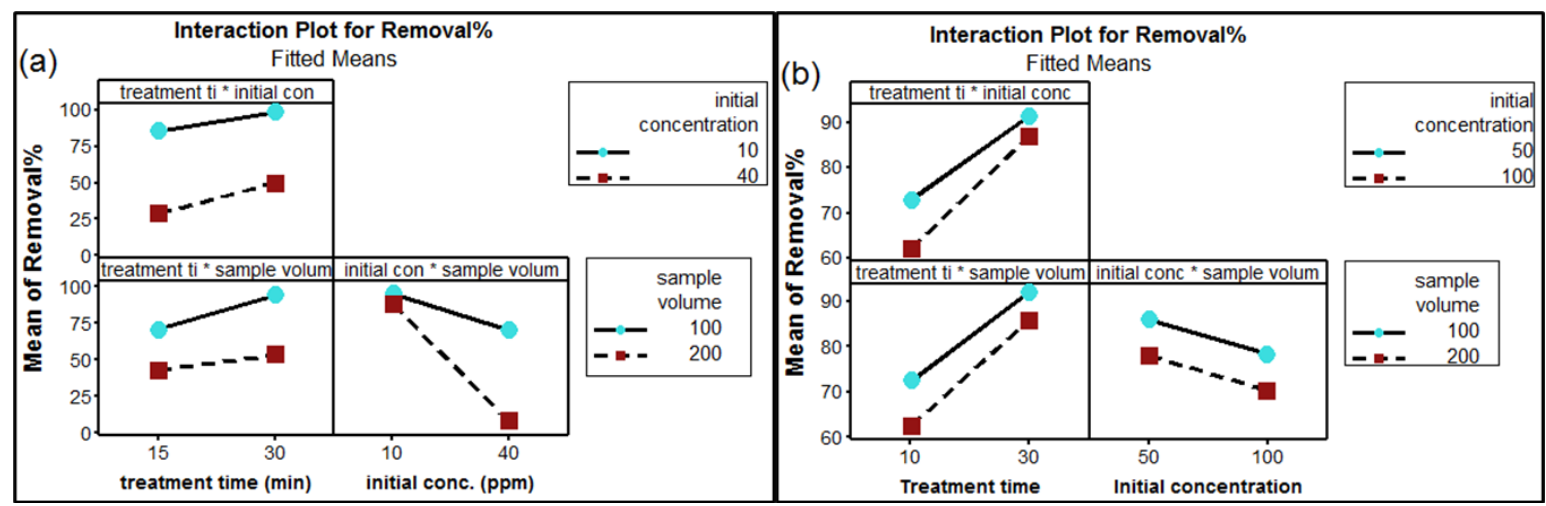

Fig.4. Interactions plots for removal efficiency of dye. Solid black lines represent low levels (-1) of the factors; dashed black lines represent high levels (1); left ends of the lines in each plot means low level of underlying factors, and the right ends depicts higher levels. 


\section{Conclusion}

Application of photocatalytic process using $\mathrm{ZnO}$ as a catalyst was capable of removing Malachite green and brilliant blue color from aqueous solutions. Most of factors (initial concentration, sample volume and treatment time) are significant according to results obtained by main effects plot, normal plot and pareto chart. In case of MG dye, the photocatalytic removal process was active at low initial concentration of MG dye (10 $\mathrm{mg} / \mathrm{L})$, small sample volume $(100 \mathrm{~mL}$ ) and long treatment time $30 \mathrm{~min}$. However, the removal\% was also found to be increased with the increasing of treatment time. It was observed that initial concentration factor (A) was the most significant factor compared to other factors as presented from pareto chart.

For BB dye, it was favoured at low initial concentration of $50 \mathrm{mg} / \mathrm{L}$ and long treatment time (30 min). Additionally, the removal percentage of dye was influenced by initial concentration, treatment time, and sample volume using $2^{3}$ full factorial experimental design. The most significant factor was treatment time (B) compared to other factor as shown in pareto chart. Two interaction factors were not significant, treatment time $v s$ sample volume and initial concentration vs sample volume.

From factorial design, the most significant factors on removal efficiency (\%) were found to be treatment time $(A)$, initial concentration $(B)$, and interaction between initial concentration and sample volume $(B C)$. Conversely, the other interactions were not effective on dye color removal.

\section{Acknowledgements}

Support for this study was provided by Malaysia-Japan International Institute of Technology (MJIIT). Management Research, Universiti Teknologi Malaysia. The authors would like to thank Universiti Teknologi Malaysia (UTM) and the Ministry of Higher Education Malaysia (MOHE) for funding this research under Grant No. 4J284 and 4F807. Furthermore, this work was also financial supported under grant Professional Development Research University (PDRU) Grant No: 04E52. Further thanks have been sent to University of Babylon, Iraq for lab assistance.

\section{References}

1. Sartape, A. S.; Mandhare, A. M.; Jadhav, V. V.; Raut, P. D.; Anuse, M. A.; Kolekar, S. S. Arab. J. Chem. 2017, 10, S3229-S3238. https://doi.org/10.1016/j.arabjc.2013.12.019

2. Raducan, A.; Olteanu, A.; Puiu, M.; Oancea, D. Cent. Eur. J. Chem. 2008, 6, 89-92. https://doi.org/10.2478/s11532-007-0066-0

3. Visited on 01/06/2020 [http://www.culinarylore.com/ingredients:fdc-blue-no-1-brilliant-blue-fcffood-dye]

4. Gao, J.; Zhang, Q.; Su, K.; Chen, R.; Peng, Y. J. Hazard. Mater. 2010, 174, 215-225. https://doi.org/10.1016/j.jhazmat.2009.09.039

5. Sakamoto, M.; Ahmed, T.; Begum, S.; Huq, H. sustainability 2019,11, 1951.https://doi.org/10.3390/su11071951

6. Aksu, Z.; Ertuğrul, S.; Dönmez, G. J. Hazard. Mater. 2009, 168, 310-318. https://doi.org/10.1016/j.jhazmat.2009.02.027

7. Doan, H. D.; Weli, A.; Wu, J.Chem. Eng. J. 2009, 151, 51-58. https://doi.org/10.1016/j.cej.2009.01.041

8. Basha, C. A.; Bhadrinarayana, N. S.; Anantharaman, N.; Begum, K. M. S. J. Hazard. Mater. 2008, 152, 71-78. https://doi.org/10.1016/j.jhazmat.2007.06.069 
9. Solisio, C.; Panizza, M.; Paganelli, P.; Cerisola, G. Resour. Conserv. Recy. 1999, 26, 115-124. https://doi.org/10.1016/S0921-3449(98)00078-0

10. Sohrabi, M. R.; Ghavami, M. J. Hazard. Mater. 2008, 153, 1235-1239. https://doi.org/10.1016/j.jhazmat.2007.09.114

11. Saien, J.; Soleymani, A. R.J. Hazard. Mater. 2007, 144, 506-512. https://doi.org/10.1016/j.jhazmat.2006.10.065

12. Faisal, M.; Tariq, M. A.; Muneer, M. Dyes Pigments 2007, 72, 233-239. https://doi.org/10.1016/j.dyepig.2005.08.020

13. Chankhanittha, T.; Nanan, S. J. Colloid Interf. Sci. 2020, 582, 412-427. https://doi.org/10.1016/j.jcis.2020.08.061

14. González-Casamachin, D. A.; De la Rosa, J. R.; Lucio-Ortiz, C. J.; De Rio, D. A. D. H.; MartínezVargas, D. X.; Flores-Escamilla, G. A.; ... Moctezuma-Velazquez, E. Chem. Eng. J. 2019, 373, 325337. https://doi.org/10.1016/j.cej.2019.05.032

15. Al-Qaim, F. F.; Abdullah, M. P.; Othman, M. R.; Khalik, W.A.N.M.A.W.A.N. Int. J. Chem. Sci. 2014, $12,62-72$.

16. Mussa, Z. H.; Al-Qaim, F. F.; Othman, M. R.; Abdullah, M. P. J. Environ. Chem. Eng. 2016, 4, 33383347. https://doi.org/10.1016/j.jece.2016.07.006

17. Mussa, Z. H.; Al-Qaim, F. F.; Yuzir, A.; Hara, H.; Azman, S.; Chelliapan, S._Catalysts 2018, 8, 540553. https://doi.org/10.3390/catal8110540

18. Al-Qaim, F. F.; Mussa, Z. H.; Yuzir, A.; Abdullah, M. P.; Othman, M. R. J. Brazil. Chem. Soc. 2018, 29, 1721-1731. https://dx.doi.org/10.21577/0103-5053.20180047 